\title{
BOVINE S PROTEIN (VITRONECTIN) INCREASES PHAGOCYTOSIS OF STREPTOCOCCUS DYSGALACTIAE
}

\author{
Laerte Francisco Filippsen* \\ Instituto Agronômico do Paraná - IAPAR, Londrina, PR, Brasil \\ Submitted: January 13, 1998; Returned to author for corrections: September 24, 1998; Approved: November 12, 1998.
}

\begin{abstract}
The effects of bovine S protein (vitronectin) on phagocytosis of Streptococcus dysgalactiae strains isolated from cattle with mastitis were investigated. Phagocytized streptococci were determined by a fluorometric microassay using glass adherent polymorphonuclear neutrophils (PMN). Preincubation of $S$. dysgalactiae with bovine $\mathrm{S}$ protein significantly increased their phagocytosis by PMN. Bovine S protein had no effect on phagocytic killing of non-S protein binding $S$. pyogenes cultures. Enzymatic digestion of the bovine S protein binding sites on $S$. dysgalactiae with pronase resulted in a significative reduction of the effects of $S$ protein on phagocytosis. It could thus be concluded that in addition to its role as a promoter of cellular adhesion and complement inhibitor, bovine $\mathrm{S}$ protein may also influence the phagocytosis of $S$. dysgalactiae during inflammatory processes.
\end{abstract}

Key words: Streptococcus dysgalactiae, bovine S protein, phagocytosis, bovine mastitis

\section{INTRODUCTION}

Streptococcus dysgalactiae, S. agalactiae and $S$. uberis are three streptococcal species frequently reported to cause bovine mastitis (9). Although the causative organisms of bovine mastitis have been identified, the exact mechanisms of the initiation and development of infection have not yet been fully elucidated.

Selective adherence of bacteria to bovine epithelium could be a prerequisite for the organism to be a successful parasite in the mammary gland (19). Also, binding of host plasma proteins to grampositive cocci might play an important role in pathogenicity $(20,15,18)$. The binding of bovine complement S protein (vitronectin) to Streptococcus dysgalactiae isolates from cattle with mastitis and its role in adherence to bovine epithelial cells were observed (4). Vitronectin is a multifunctional protein that has important role in complement-dependent cell lysis (7), in the coagulation system (12), and in cellular adhesion (2). The bovine $\mathrm{S}$ protein exists in plasma with molecular weight of 76,000 and 65,000 (4) and its biological properties were indicated by the ability to spread cultured endothelial cells, as described for human $\mathrm{S}$ protein (11). The purpose of this study was to determine the effects of bovine $\mathrm{S}$ protein binding by $S$. dysgalactiae on its phagocytosis by bovine polymorphonuclear neutrophils (PMN).

\footnotetext{
* Corresponding author. Mailing address: IAPAR, Caixa Postal 481, CEP 86001-970, Londrina, PR, Brasil. Fax: (+5543) 376-2101. E-mail: laerte@pr.gov.br
} 


\section{MATERIALS AND METHODS}

Streptococci. Four clinical isolates of $S$. dysgalactiae recovered from cattle with mastitis were used. In addition, two cultures of $S$. pyogenes (lacking the capacity to bind bovine $\mathrm{S}$ protein) served as controls. Each strain was inoculated in 1-litre Erlenmeyer flasks containing $100 \mathrm{ml}$ of Todd-Hewitt broth (GIBCO/BRL, GmbH, Eggstein, Federal Republic of Germany). After incubation on a rotary shaker for $18 \mathrm{~h}$ at $37^{\circ} \mathrm{C}$ and $60 \mathrm{rpm}$, the bacteria were harvested by centrifugation for $20 \mathrm{~min}$ at $15,000 \mathrm{xg}$.

For proteolytic treatments, two $S$. dysgalactiae strains (S.dys 8 and S.dys 12) with the highest $\mathrm{S}$ protein binding activities were used. One $\mathrm{ml}$ samples of suspensions containing $10^{8}$ streptococcal cells $/ \mathrm{ml}$ were incubated with increasing $(2,5$ to $250 \mu \mathrm{g})$ concentrations of pronase (E. Merck AG, Darmstadt, Germany) as described (3).

Purification of bovine $S$ protein. S protein was purified from bovine plasma as previously described (4). The purity of the protein was tested by sodium dodecyl sulfate polyacrylamide gel electrophoresis (8) and western blot analysis (16) with anti-bovine S protein antibodies. Antibodies against bovine $\mathrm{S}$ protein were raised in rabbits.

Radioiodination and binding assays. $\mathrm{S}$ protein was radiolabeled with ${ }^{125} \mathrm{I}$ (Carrier Free, Amersham Buchler, Braunschweig) using the chloramine-T method (6). The specific activity of each of the 3 preparations was approximately $1.4 \mathrm{mci} / \mathrm{mg}$ of protein. Radiolabelled S protein was analysed by sodium dodecyl sulfate polyacrylamide gel electrophoresis (8). The binding assays were performed as previously described (4), using $2 \times 10^{8}$ streptococci and $10 \mathrm{mg}$ of the respective ${ }^{125}$ I-labelled protein in $0.15 \mathrm{M}$ phosphatebuffered saline solution (PBSS, $\mathrm{pH}$ 7.5) containing $0.05 \%$ Tween 20 (PBSS-Tween). After $1 \mathrm{~h}$ at $25^{\circ} \mathrm{C}$, the streptococci were centrifuged for $3 \mathrm{~min}$ at 10,000 $\mathrm{xg}$ and washed with ice-cold PBSS-Tween. The radioactivity in the sediment was measured in a $\gamma$ spectrometer (Packard Instrument Co., Inc., Rockville, MD). The radioactivity uptake was expressed as percentage of the total activity remaining in the pellet.

Preparation of polymorphonuclear neutrophils (PMN). PMN were prepared from ethylenediaminetetraacetic acid (EDTA) treated bovine blood using ficoll-hypaque gradients (Histopaque, Sigma, Munich, Federal Republic of Germany). Remaining erythrocytes were lysed with $0.162 \mathrm{M}$ ammonium chloride (pH 7.2) and the sedimented PMN washed twice in Hanks balanced salt solution (HBSS), containing $0.1 \%$ bovine serum albumin. Cell viability was higher than $95 \%$ as determined by trypan blue dye exclusion test. The PMN suspensions were adjusted to $5 \times 10^{6}$ cells $/ \mathrm{ml}$ using a hemocytometer.

Phagocytic assays. The method of Rainard (14) for the phagocytic assays was used essentially as previously described (17). Streptococcal suspensions $\left(10^{8}\right.$ streptococci $/ \mathrm{ml}$ in HBSS) were incubated with 3 to $300 \mu \mathrm{g}$ of bovine $\mathrm{S}$ protein for $30 \mathrm{~min}$ at $37^{\circ} \mathrm{C}$. Subsequently, the streptococci were washed in HBSS, opsonized with free $\mathrm{S}$ protein bovine serum at a final concentration of $10 \%$ and used in phagocytic assays. Phagocytosis was observed on glass-adherent polymorphonuclear neutrophils. One hundred $\mathrm{ml}$ of PMN suspensions were dripped on microscopic slides and, after incubation for $1 \mathrm{~h}$ at $37^{\circ} \mathrm{C}$ under $5 \% \mathrm{CO}_{2}$, the preparations were washed with HBSS. Streptococcal suspension $(100 \mu \mathrm{l})$ were added and after incubation for $1 \mathrm{~h}$ at $37^{\circ} \mathrm{C}$ under $\mathrm{CO}_{2}$, the preparations were washed twice with HBSS and stained with an acridine orange (Sigma) solution $(20 \mu \mathrm{g} / \mathrm{ml}$ in HBSS) for $1 \mathrm{~min}$ at room temperature. The slides were washed with HBSS, mounted with cover slips, sealed with paraffin and examined with a fluorescence microscopic. Viable streptococcal cells appeared in green and intracellular killed streptococci appeared in red (10). The phagocytized streptococci, in at least 50 randomly selected PMN, were counted. In controls either PMN or streptococci were replaced by HBSS.

\section{RESULTS AND DISCUSSION}

The purified bovine $\mathrm{S}$ protein migrated as a doublet, with molecular weight of 76,000 and 65,000, in the sodium dodecyl sulfate polyacrylamide gel electrophoresis (Fig.1). The purified preparation had a characteristic doublet when analysed by immunoblotting (Fig. 2), but did not cross-react with antibodies against human or bovine fibronectin (4) . The functional properties of $\mathrm{S}$ protein were demonstrated by its ability to facilitate the spreading of cultured endothelial cells (11), to inhibit complement-dependent lysis and to neutralize the anticoagulant activity of heparin in the thrombinantithrombin III reaction $(12,13)$.

The four strains of $S$. dysgalactiae bound ${ }^{125} \mathrm{I}-$ labeled bovine $\mathrm{S}$ protein with a mean value of $45 \%$ and those of $S$. pyogenes did not interact with this protein. Therefore $S$. pyogenes served as a negative control in the phagocytic assays. 


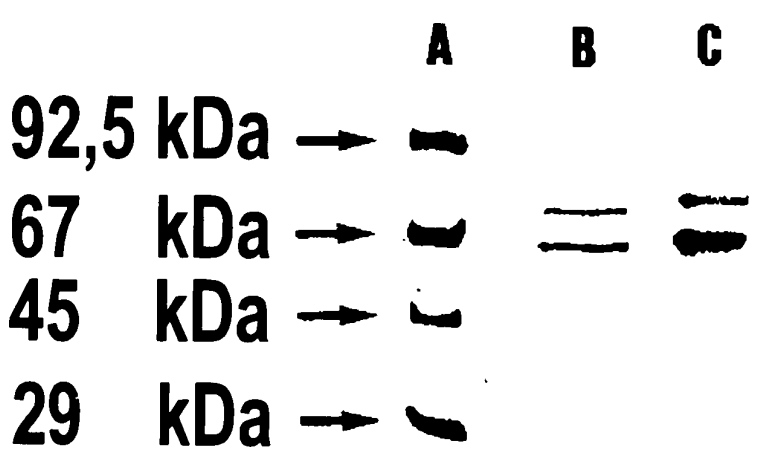

Figure 1 - SDS-Polyacrylamide gel electrophoresis of purified bovine S protein. Lanes: A, size markers (phosphorylase B, $92,5 \mathrm{kDa}$; bovine serum albumin, $67 \mathrm{kDa}$; ovalbumin, $45 \mathrm{kDa}$; carbonyc anhydrase, 29 $\mathrm{kDa}) ; \mathbf{B}$, human S protein; $\mathbf{C}$, purified bovine S protein.

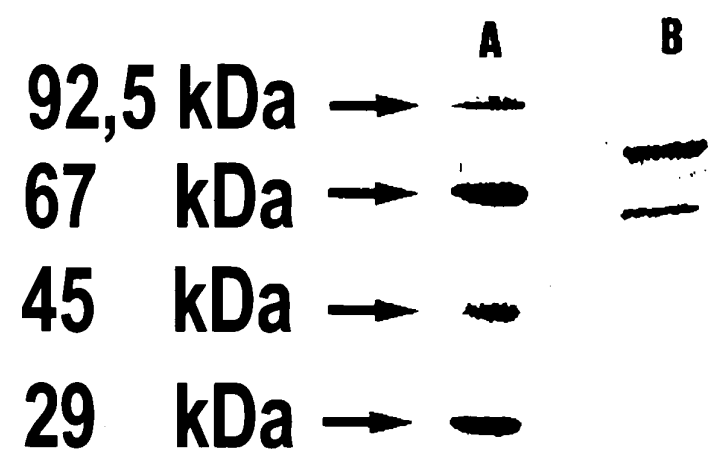

Figure 2 - Western blot of purified bovine S protein using antibovine S protein antibodies. Lanes: A, size markers (phosphorylase $\mathrm{B}, 92,5 \mathrm{kDa}$; bovine serum albumin, $67 \mathrm{kDa}$; ovalbumin, $45 \mathrm{kDa}$; carbonyc anhydrase, $29 \mathrm{kDa}$ ); B, purified bovine $\mathrm{S}$ protein.

In the phagocytic assays, prior incubation of $S$. dysgalactiae strains with bovine $\mathrm{S}$ protein significantly increased their phagocytosis by bovine polymorphonuclear neutrophils. A phagocytic increase of almost $120 \%$ was observed when $300 \mu \mathrm{g} /$ $10^{8}$ streptococcal cells were applied (Fig. 3). Preincubation of $S$. pyogenes strains with the same concentration of bovine $\mathrm{S}$ protein did not affect their phagocytosis. To further elucidate the involvement of bovine $\mathrm{S}$ protein binding sites in the phagocytic killing of $S$. dysgalactiae, streptococci were treated with proteolytic enzymes prior to phagocytosis assays. After enzymatic digestion of the streptococcal binding sites for $\mathrm{S}$ protein with pronase, the effects of bovine $\mathrm{S}$ protein on $S$. dysgalactiae phagocytosis were reduced (Fig. 4).

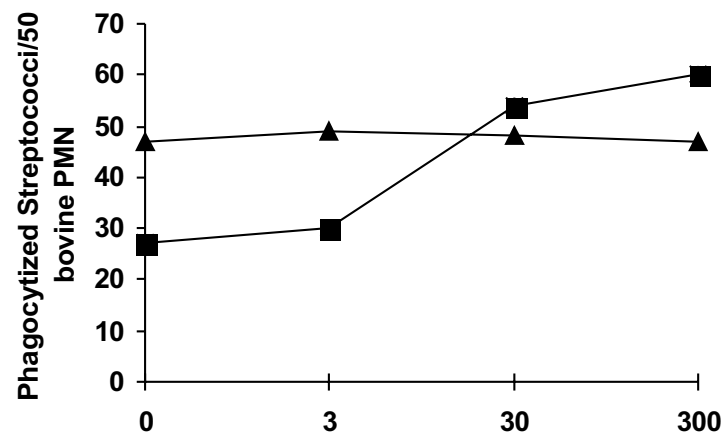

bovine $S$ protein $(\mathrm{ug} / \mathrm{ml})$

Figure 3 - Phagocytosis of Streptococcus dysgalactiae $(\square)$ and Streptococcus pyogenes $(\boldsymbol{\Delta})$ by bovine polymorphonuclear neutrofils after preincubation of streptococci with increasing concentrations (3-300 $\mu \mathrm{g} / \mathrm{ml}$ ) of bovine $\mathrm{S}$ protein. Results represent means obtained with four cultures of $S$. dysgalactiae and two cultures of $S$. pyogenes.

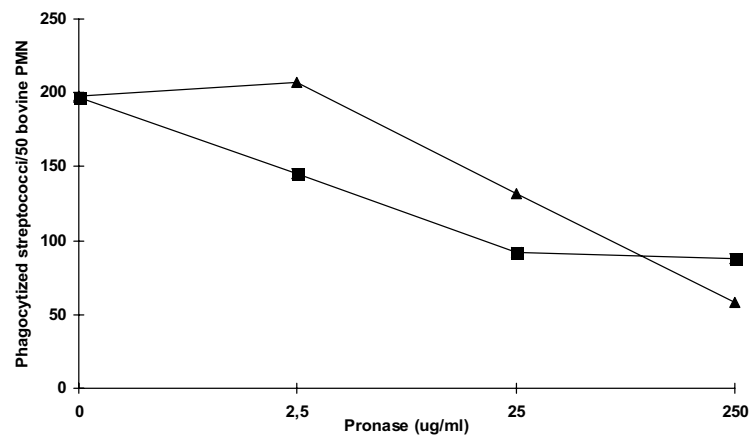

Figure 4 - Phagocytosis of Streptococcus dysgalactiae, strains S.dys $8(\boldsymbol{\square})$ and S.dys $12(\boldsymbol{\Delta})$, by bovine polymorphonuclear neutrofils after treatment with increasing concentrations $(2.5-250 \mu \mathrm{g} / \mathrm{ml})$ of pronase, in the presence of bovine S protein $(100 \mu \mathrm{g} / \mathrm{ml})$. Each point represents mean of duplicates.

Intramammary infections of dairy cows caused by $S$. dysgalactiae have been characterized by persistence of the infection and by a poor response to conventional control measures. Significant differences in intramammary infectivity and binding capacities among certain strains of $S$. dysgalactiae were reported $(5,4)$. Previous reports $(4,1)$ demonstrated that $S$. dysgalactiae strains could adhere and invade bovine epithelial cells, induced cellular damage, and were capable of persisting inside bovine mammary epithelial cells.

Phagocytosis by polymorphonuclear neutrofils is one of the first defense lines against invading streptococci and the specific interaction of streptococci with fibrinogen plays an important role as an antiphagocytic factor $(20,17)$. In adherence 
experiments, bovine $\mathrm{S}$ protein enhanced streptococcal adherence to bovine epithelial cells (4). However, no studies about the influence of $\mathrm{S}$ protein in the phagocytosis of $S$. dysgalactiae were described. This study presents evidence that binding of bovine $\mathrm{S}$ protein by $S$. dysgalactiae increased phagocytosis by $\mathrm{PMN}$. The involvement of the specific $\mathrm{S}$ protein binding structures of $\mathrm{S}$. dysgalactiae in the phagocytosis could be confirmed by assays using proteolyzed streptococci, a procedure known to destroy $\mathrm{S}$ protein binding activities of $S$. dysgalactiae (4). The results of the present study indicate that in addition to its role as a promoter of cellular adhesion and complement inhibitor $(7,2), \mathrm{S}$ protein may also influence the phagocytosis during inflammatory processes. These data will be helpful in the elucidation and understanding of the pathogenesis of $S$. dysgalactiae bovine mastitis and the exact relationship between bovine $\mathrm{S}$ protein binding, adherence and infectivity .

\section{RESUMO}

\section{Aumento na fagocitose de Streptococcus dysgalactiae pela ação da proteína $S$ bovina (vitronectina)}

Foram investigados os efeitos da proteína $\mathrm{S}$ bovina (vitronectina) na fagocitose de amostras de Streptococcus dysgalactiae isoladas de bovinos com mastite. A determinação do número de estreptococos fagocitados foi realizada pelo método fluorométrico utilizando neutrófilos polimorfonucleares (NPM) aderidos em lâminas de vidro. A pré-incubação do $S$. dysgalactiae com a proteína $\mathrm{S}$ bovina aumentou significativamente a sua fagocitose por NPM. A proteína $\mathrm{S}$ bovina não causou efeito na fagocitose de culturas de $S$. pyogenes, já que não apresentam sítios de ligação para esta proteína. A digestão enzimática com pronase dos sítios de ligação $S$. dysgalactiae para a proteína $S$ bovina resultou numa significativa redução do efeito da proteína $\mathrm{S}$ na fagocitose. Pode-se concluir que além do papel como promotor da adesão celular e inibidor do complemento, a proteína $\mathrm{S}$ bovina pode também influir na fagocitose do $S$. dysgalactiae durante os processos inflamatórios.

Palavras-chave: Streptococcus dysgalactiae, proteína $\mathrm{S}$ bovina, fagocitose, mastite bovina.

\section{REFERENCES}

1. Almeida, R.A.; Oliver, S.P. Invasion of bovine mammary epithelial cells by Streptococcus dysgalactiae. J. Dairy Sci., 78: 13101317, 1995.

2. Barnes, D.; Wolfe, R.; Serrero, G.; McClure, D.; Sato, G. Effects on a serum spreading factor on growth and morphology of cells in serum-free medium. J. Supramol. Struct., 14: 47-63, 1980.

3. Chhatwal, G.S.; Preissner, K.T.; Müller-Berghaus, G.; Blobel, H . Specific binding of the human S-Protein (vitronectin) to streptococci, Staphylococcus aureus and Escherichia coli. Infect. Immun., 55: 1878-1983, 1987.

4. Filippsen, L.F.; Valentin-Weigand, P.; Blobel, H.; Preissner, K.T.; Chhatwall, G.S. Role of complement S-Protein (vitronectin) in adherence of Streptococcus dysgalactiae to bovine epithelial cells. Am. J. Vet. Res., 51: 861-865, 1990.

5. Higgs, T.M.; Neave, F.K.; Bramley, A.J. Differences in intramammary pathogenecity of four strains of Streptococcus dysgalactiae.J. Med. Microbiol., 13: 393-399, 1980.

6. Hunter, W.H.; Greenwood, F.C. Preparation of iodine-131 labelled human hormon of high specific activity. Nature, 194: 495-496, 1962.

7. Kolb, W.P.; Müller-Eberhard, H.J. The membrane atack mechanism of complement: isolation and subunit composition of the C5b-9 complex. J. Exp. Med., 141: 724-735, 1975.

8. Laemmli, U.K. Cleavage of structural proteins during the assembly of the head of bacteriophage T4. Nature, 227: 680-685, 1970.

9. Lee, C.S.; Furst, A.J. Mastitis in slaughtered dairy cows. I. Udder infection. Aust. Vet. J., 46: 20-23, 1970.

10. Pantazis, C.G.; Kniker, W.T. Assessment of blood leukocyte microbial killing by using a new fluorochrome microassay. $R$. Reticuloendothel. Soc., 26: 155-170, 1979.

11. Preissner, K.T.; Heimburger, N.; Anders, E.; Müller-Berghaus, G. Physicochemical, immunochemical and functional comparison of human S-Protein and vitronectin-evidence for the identity of both plasma proteins. Biochem. Biophys. Res. Commum., 134: 951-956, 1986

12. Preissner, K.T.; Müller-Berghaus, G. S-Protein modulates the heparin-catalysed inhibition of thrombin by antithrombin III. Evidence for a direct interaction of S-Protein with heparin. Eur. J. Biochem., 156: 645-650, 1986.

13. Preissner, K.T.; Wassmuth, R.; Müller-Berghaus, G. Physicochemical characterization of human S-Protein and its function in the blood coagulation system. Biochem. J., 231: 349355,1985 .

14. Rainard, P. Assessment by a fluorochrome microassay of phagocytic killing of group B streptococci adherent to glass. $J$. Immunol. Methods, 94: 113-118, 1986.

15. Simpson, W.A.; Beachey, E.H. Adherance of group A streptococci to fibronectin and oral epithelial cells. Infect. Immun., n. 39: 275-279, 1983.

16. Towbin, H.; Staehelin, T.; Gordon, J. Electrophoretic transfer of proteins from polyacrylamide gels to nitrocellulose sheets: procedure and some applications. Proc. Natl. Acad. Sci. USA, 76: 4350-4354, 1979.

17. Traore, M.Y.; Valentin-Weigand, P.; Chhatwal, G.S.; Blobel, H. Inhibitory effects of fibrinogen on phagocytic killing of streptococcal isolates from human, cattle and horses. Vet. Microb., 28: 295-302, 1991.

18. Valentin-Weigand, P.; Gruhlich-Henn, J.; Chhatwal, G.S.; MüllerBerghaus, G.; Blobel, H.; Preissner, K.T. Mediation of adherence of streptococci to human endothelial cells by complement SProtein (vitronectin). Infect. Immun., 56: 2851-2855, 1988.

19. Wanasinghe, D.D. Adherence as a prerequisite for infeccion of the mammary gland by bacteria. Acta. Vet. Scan., 22: 109-117, 1981.

20. Whitnack, E.; Beachey, E.H. Antiopsonic activity of fibrinogen bound to M Protein on the surface of group A streptococci. $J$. Cli. Invest., 69: 1042-1045, 1982. 